January 1999

\title{
Stock Compensation: The Most Expensive Way to Pay Future Cash
}

Calvin $\mathrm{H}$. Johnson

\section{Recommended Citation}

Calvin H. Johnson, Stock Compensation: The Most Expensive Way to Pay Future Cash, 52 SMU L. REV. 423 (1999)

https://scholar.smu.edu/smulr/vol52/iss2/6

This Article is brought to you for free and open access by the Law Journals at SMU Scholar. It has been accepted for inclusion in SMU Law Review by an authorized administrator of SMU Scholar. For more information, please visit http://digitalrepository.smu.edu. 


\title{
Stock Compensation: The Most Expensive Way to Pay Future Cash
}

\author{
Calvin H. Johnson*
}

\section{TABLE OF CONTENTS}

I. INTRODUCTION ............................ 424

II. STOCK COMPENSATION IS MORE EXPENSIVE

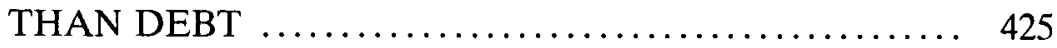

A. Stock is a Proxy for Future Cash ............ 425

1. Value from Sale Price ..................... 426

2. Value from Accumulated Earnings............. 427

B. Cost Compared to Debt: The Extraordinary

Premium on Stock ......................... 428

1. Pretax Discount Rates ...................... 428

2. Tax Deduction for Interest ................... 429

3. Higher Return Corporations ................. 431

4. Current Conditions ....................... 431

C. Explaining the Extraordinary Cost of Stock... 432

1. Volatility ............................... 432

2. Agency Explanation ....................... 435

III. STOCK COMPENSATION IS MORE EXPENSIVE THAN CASH DEFERRED COMPENSATION ........ 440

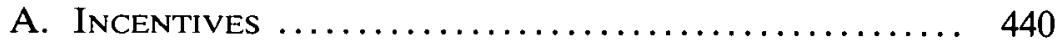

1. Drawbacks of Stock as an Incentive Device ....... 441

2. Stock Option Distortions ..................... 442

3. Incentives with Deferred Payment of Cash ........ 444

B. Reducing the Discount Rate ................. 445

1. The Value of an Enforceable Promise........... 445

2. Rabbi Trusts ........................... 446

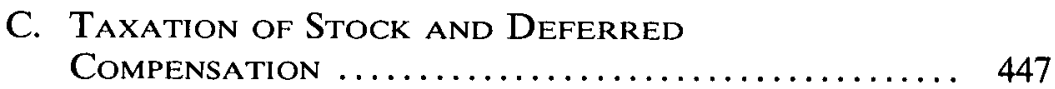

1. Model 1: Appreciation Only .................. 448

2. Model 2: Nullification of Capital Gain .......... 449

IV. A NOTE ON COMPARING STOCK COMPENSATION WITH CURRENT CASH $\ldots \ldots \ldots \ldots \ldots \ldots \ldots \ldots \ldots, 452$

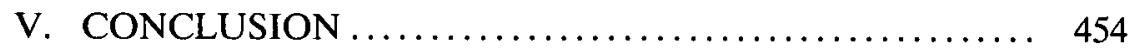

* Andrews \& Kurth Centennial Professor of Law, University of Texas, Austin. 


\section{INTRODUCTION}

$\mathrm{S}$ ILICON Valley is said to be a "stock option culture" because the high technology start-up companies rely so heavily on stock compensation. ${ }^{1}$ Start-up companies, it is said, need stock options to motivate employees. ${ }^{2}$ High technology companies have tenaciously defended the accounting treatment of stock options that allows the companies to avoid reporting any compensation cost on their reports to shareholders when stock options are used as compensation. ${ }^{3}$ The "stock option culture," it is said, is "taking over the country." 4 Almost all of the largest publicly traded firms in the United States permit granting stock options to executives, and in every industry surveyed, the median option grant is larger than the salary for the Chief Executive Officer. ${ }^{5}$

Stock-based compensation, however, is a particularly expensive way for the issuer to pay employees. For the issuer, stock is just a proxy for the future cash that will need to be paid out on the stock. The issuer gets credit for the future cash it will pay on stock only at its present value. The discount rate used to compute the present value of cash paid out on stock is brutal for the issuer, far higher than it would be with other forms of compensation. The high discount rate means that the corporate employer gets no material credit for the cash that it has committed to the employee and will eventually need to pay out on the stock. Using stock as compensation undervalues the issuer's ultimate sacrifice.

Discount rates are so high on stock because stock prices are so volatile and because the market distrusts managers. Shareholders are risk-averse and volatility is a noxious characteristic for risk-averse shareholders. Shareholders react to volatility unkindly by driving up the discount rate used to value the future cash from the stock and driving down the value of the stock. Shareholders, moreover, distrust managers to be loyal to their interests so that they discount assets accumulated within the corporation at high discount rates.

For the issuer the resulting high discount rate on stock is brutal. Noxious volatility from factors outside the firm is not a necessary part of compensation. General market or industry-wide volatility can be filtered out

1. See Justin Fox, The Next Best Thing to Free Money, Fortune, July 7, 1997, at 52 .

2. See Sen. Joseph I. Leiberman, But They Do Create Good Jobs, L.A. Times, Apr. 8, 1994 , at B7.

3. See, e.g., Stephen A. Zeff, The U.S. Senate Votes on Accounting for Employee Stock Options, in Readings \& Notes on Financial Accounting 507, 512 (Stephen A. Zeff \& Bala G. Dharan eds., 5th ed. 1997) (reporting a Vietnam-era-style demonstration when hearings were conducted in San Jose, California, on a proposal to include stock options as a cost of compensation in reported company earnings); Christi Harlan, High Anxiety: Accounting Proposal Stirs Unusual Uproar in Executive Suites, WALL. ST. J., Mar. 7 , 1994, at A1; Lee Berton, Accounting Rules Board is Under Fire as It Nears Decision on Two Key Issues, WALL Sr. J., Apr. 6, 1993, at A2 (stating that outside criticism is rapidly mounting and that survival of Financial Accounting Standards Board may be at stake).

4. Fox, supra note 1 , at 52 .

5. See M.A. Klein, Top Executive Compensation: 1995 Edition, (Conference Board Report, 1995) (reporting that $87 \%$ of largest firms authorize executive stock option). 
of compensation if the parties use deferred cash plans, instead of stock compensation. Managers can get more credit for future cash they will pay out by increasing their credibility that the cash will in fact be available.

Stock is more expensive for the issuer than other available alternative ways to pay future cash, that is, debt and deferred compensation payable in cash. The discount rate on debt-interest-is far lower for the issuer than is the discount rate on stock. Tax deductions for interest on debt, but not for distributions on stock, make debt even cheaper. In fact, the average cost of interest, after tax and after inflation, has been negative, over long periods of time. Negative interest means that the real cost of compensation gets lower the more the compensation is deferred. Both debt and deferred compensation increase the value that the employer gets for its future cash, by increasing the issuer's credibility and lowering the discount rate applied to stock.

Stock is often touted as a way to give capital gain to employees because capital gain is taxed at lower rates than ordinary income compensation. Giving capital gain to employees, however, is usually poor tax planning, viewing employer and employee in aggregate. There is, for example, a "nullification of capital gains" theorem, true within the range of "normal" capital gains, that deferred cash compensation will give the employee an after-tax benefit that is as good as having no tax on capital gain.

The trouble with stock compensation suggests that a conscientious manager, trying to be fair and loyal to his firm and outside shareholders, should avoid using stock and stock options as compensation. Stock compensation is sometimes touted as aligning management with shareholder interests. Stock, however, is just another way to hurt the shareholders because it uses the most expensive format by which to pay management. Stock-based compensation should not be favored by business norms, and it should not be favored by the accounting, securities, and corporate law provisions that attempt to civilize the self-interested behavior of management.

Part II compares stock compensation with debt given as compensation and argues that debt is cheaper than stock as a way to pay future cash to employees. Part III compares stock compensation to deferred cash plans and argues that deferred cash compensation is cheaper than stock. Cash plans are also a superior incentive device. Part IV compares stock compensation with current cash compensation.

\section{STOCK COMPENSATION IS MORE EXPENSIVE THAN DEBT}

\section{A. Stock is a Proxy for Future Cash}

By issuing stock to an employee, the corporation has committed a fraction of its future cash to the employee. ${ }^{6}$ By issuing stock, the corporation

6. See, e.g., Thomas Copeland \& J. Fred Weston, Financial Theory and CorPORATE POLICY 21-22 (3d ed. 1988) (arguing that stock represents discounted present 
has not promised the employee to make any payments. Dividend distributions or redemption of the stock cannot be compelled by a shareholder. Under the business judgment rule, the courts delegate the decision as to whether to distribute cash to shareholders to the discretion of the board of directors. ${ }^{7}$ Nonetheless, the basic rule is that dividends and liquidation proceeds must be equal for all shares of the same class, without preference or discrimination. ${ }^{8}$ A toddler learns early in day care or with siblings to cry "share," and the cry works fairly well as a remedy for shareholders too. By giving stock to employees, the corporation has promised to share its future cash between old shareholders and the employees.

A founder of a corporation who has given a new employee $10 \%$ of the stock of the business has given up $10 \%$ of the residual cash of the business. Employees receiving a stock bonus or buying stock under an option cannot gain anything from their stock, except symmetrically by drawing value away from existing shareholders. Stock has value only because it produces cash.

Sometimes the effect of cash distributions on the value of stock is indirect. The return that shareholders get from shares includes the proceeds from sale of the shares to other investors. Accumulated earnings contribute to the sale price for stock, even though they are not distributions. Both sale proceeds and value from accumulated earnings depend, in turn, however, upon the present value of future cash distributions on the shares.

\section{Value from Sale Price}

The subsequent sale price for a share of stock is nothing but the price that a willing buyer will pay for it. ${ }^{9}$ A rational buyer pays no more for the stock than the net present value of the cash that is expected after the sale. If the present buyer is in turn relying on selling the stock to some further

value of cash distributions). See also Calvin H. Johnson, The Legitimacy of Basis from a Corporation's Own Stock, 9 AM. J. TAx PoL'y 155 (1991) (arguing that fair market value of stock represents a real cost to the issuer because it is net present value of future, nondeductible cash).

7. See, e.g., Dodge v. Ford Motor Co., 170 N.W. 668 (Mich. 1919) (holding that a corporation may be forced to distribute dividends only upon compelling evidence that management was ignoring shareholder interest); Panter v. Marshall Field \& Co., 646 F.2d 271, 293 (7th Cir. 1981) (holding that "in the absence of fraud, bad faith, gross overreaching or abuse of discretion," courts will not interfere with corporate directors' business judgment). For a debate over whether management discretion should be highlighted for investors, compare Victor Brudney, Dividends, Discretion, and Disclosure, 66 VA. L. REv. 85 (1980) (arguing that given conflict of interests between management and shareholders, disclosure of meaning of dividend decisions should be required) with Daniel $R$. Fischel, The Law and Economics of Dividend Policy, 67 VA. L. REv. 699 (1981) (arguing that market discipline is sufficient).

8. See 11 William Meade Fletcher et al., Fletcher Cyclopaedia of the Law of Private Corporations 915352 at $733-734$ (1995); 18B Am. Jur. 2D Corporations $\$ 1220$ (1985).

9. See, e.g., Werner F.M. De Bondt \& Richard H. Thaler, Anomalies: A Mean-Reverting Walk Down Wall Street, 3 J. Econ. Persp. 189 (1989). 
buyer, that further buyer must still be relying on the present value of subsequent cash flows. Some shareholders make money on "the greater fool" theory by finding someone to buy the stock for more than the seller paid without regard to present value of subsequent cash flows. But an investor relying on the greater fool is already pretty far down the road to foolishness. Buyers are usually self-protecting and rational and pay only the present value of the cash flows expected to be distributed by the corporation after the buyer's purchase. Ultimately, it is only the expectation of cash distributions that gives any value to the shares.

\section{Value from Accumulated Earnings}

Stock is also commonly priced by looking to the earnings of the corporation, including earnings that are not distributed. Still, for accumulated earnings to have value, the earnings must be like compound interest on a bank account: leaving the interest on deposit, instead of withdrawing it, must mean that the interest will earn interest. To have value, accumulated earnings must increase the cash that is ultimately withdrawable. If management is going to waste the accumulated earnings on bad investments or looting compensation, then the accumulations do not contribute to share value. Thus, even growth stocks that are expected to give no distributions for the foreseeable future have value only because accumulations and the sale price are proxies for cash to be distributed in the future.

Even unexpected increases in stock price after the corporation issues stock as compensation represent a cost to the corporation. A broad market such as the New York Stock Exchange is an efficient or "smart market" in which bargaining between buyers and sellers reflects publicly available information very quickly. ${ }^{10}$ The future is ultimately unknowable, so that market price will not be correct. Market price, however, is the best estimate of discounted present value of cash distributions reached by parties bargaining at arm's length and using all available information to maximize their own self-interest. If the price of the issuer's stock goes up by $40 \%$ unexpectedly, the smart market has determined that the discounted present value of the future cash distributions has gone up by $40 \%$. Cash distributions are the ultimate cost of stock to the issuer, however, and fair market value of the stock just reflects a new appraisal of the issuer's real cost.

Much of the popularity of stock compensation seems to arise from a fallacy that stock is cost free. ${ }^{11}$ The issuing corporation can print its own stock, whereas it cannot print cash. "Dilution" does not seem to convey the idea of cost to the issuer. Much of the cash that gives stock its value will be paid long in the future; much of the cash will be paid out beyond

10. See e.g., Burton G. Malkiel, Is the Stock Market Efficient?, 243 SCIENCE 1313, 1317 (Mar. 10, 1989).

11. See, e.g., Fox, supra note 1, at 58 (stating, about stock options, "Because remember: They're free."). 
the time horizon that practical managers can see. In general accepted accounting, stock options may be reported on income statements as if they were free. ${ }^{12}$ Still, giving employees an option to buy stock of the issuer is also just a proxy for future cash that will be issued if the option is exercised. Issuing shares means that the corporation has to view itself as committing cash to the new employee if the stock is worth anything at all. Stock and stock compensation compete with other ways to pay employees with future cash, and the alternative means, debt and deferred compensation, are cheaper.

\section{B. Cost Compared to Debt: The Extraordinary Premium ON STOCK}

\section{Pretax Discount Rates}

Investments in stock persistently have a higher return than investments in corporate debt over a long period of time. According to data collected by Ibbotson Associates, a dollar invested in long-term corporate bonds at the end of 1925 until the end of 1997 would have given annual compound interest of $2.6 \%$, measured after inflation. ${ }^{13} \mathrm{~A}$ dollar invested in large company stocks over the same period would have given an annual compound return of $7.7 \%$, measured after inflation. ${ }^{14}$

An extraordinary premium return to investors is symmetrically a brutal cost to the issuer. Debt is extraordinarily cheap to an issuer and stock is extraordinarily expensive. Assume, for instance, that a corporate employer gives a $\$ 1000$ stock bonus to an employee, pays no dividends on the stock and then redeems the stock back seventy-two years later after the stock has grown in price by the average or $7.7 \%$ growth rate. The corporation would need to pay $\$ 203,000$ in cash to redeem the stock. Stock is a very long lasting instrument for an issuer, so some very long period is appropriate for evaluating stock. Long-term perspectives also filter out or average out some accidental or temporary explanations. The

12. Current accounting rules allow a corporation to report stock options issued as compensation as having no cost to the corporation if paid pursuant to an option had no bargain when the stock amount and option price were set. See Accounting For STockBased Compensation, Statement of Financial Accounting Standard No. 123 qI 26 (Financial Accounting Standards Bd. 1995) (allowing continuation of Accounting Principles Board, opinion No. 25 I 10 ). For a criticism of the rule and discussion of accounting for stock options, see Calvin H. Johnson, Accounting in Favor of Investors, 19 Cardozo L. Rev. 637, 643-648 (1997); Calvin H. Johnson, Stealing the Company with Free Stock Options: The Furor over Accounting Standards (pts. 1 \& 2), 65 TAx Notes 355 (1994), 65 TAx Notes 479 (1994); Calvin H. Johnson, Professor Johnson Replies to FASB, 65 TAX Notes 1149 (1994).

13. A dollar invested at the end of 1925 would be worth $\$ 6.16$. Iввотson Associates, Stocks, Bonds, Bills and Inflation 1998 Yearbook 104-05 (1998). Since \$1* (1 $+i)^{72}=6.155$, so $i=\left({ }^{72} 6.155\right)-1=2.56 \%$. Any comparisons of long-term investments need to be made in constant value dollars, from which inflation has been excluded, because the buying power gives a dollar its real meaning.

14. A dollar invested in large company stocks over the same period would have grown to $\$ 203.19$ in constant dollars. See lBBOTSON Associates, supra note 13, at 104-105. Since $\$ 1 *(1+i)^{72}=203.19$, so $i=\left({ }^{72} 203.19\right)-1=7.66 \%$ 
$\$ 203,000$ redemption price reflects just the average cost for large corporations in the Ibbotson sample.

Assume, by contrast, that the corporation gave a $\$ 1000$ indebtedness to the employee as a bonus, and that, like the stock, the issuer pays all the cash, both principle and interest, at the end of the same seventy-two-year term. ${ }^{15}$ The $2.6 \%$ real growth of the debt, means that the debt bonus is redeemed for $\$ 6155$, in real constant-value-dollar terms. The $\$ 203,000$ redemption price for the stock given as compensation is thirty-threetimes the $\$ 6155$ cash redemption price for the debt given for the same $\$ 1000$ of compensation.

The return on stock can also be expressed in terms of how much credit the employee will give to the corporation currently in return for the corporation's future cash. Future cash on stock or debt gives fair market value now to employees only because of the present value of the cash reflected in the value of the instrument. A corporation paying the constant-value-dollar amount of $\$ 1$ in seventy-two years in the form of payment on debt will get credit for giving current compensation of sixteen cents. ${ }^{16} \mathrm{~A}$ corporation paying the same dollar in the form of stock will get current credit of only a near invisible value of half a cent. ${ }^{17}$ Stock is an undervalued form to pay cash in the future. For the corporation to get any material current credit for the cash it will ultimately pay, it will need to issue debt.

\section{Tax Deduction for Interest}

The disparity between the high discount rate on stock and the cheap cost of debt is made even greater by tax. Interest on debt is deductible by the issuer, but distributions on stock are not. ${ }^{18}$ The amount deductible on

15. Debt will not ordinarily have such a long term, but a corporation will have debt for its full existence so that the corporation's debt will be renewed or replaced. The renewals or replacements can be tacked together as a continuous single pool of debt, as if there were only one debt.

16. $\$ 1 / 6.155=\$ 0.162$.

17. $\$ 1 / 203=\$ 0.0049$.

18. For interest to be deductible, the debt must be a bona fide debt for tax purposes, payable without regard to the success or failure of the firm. A major economic test of whether debt is bona fide is whether a third-party creditor would be willing to lend the funds to the debtor-employer. See, e.g., Bauer v. Commissioner, 748 F.2d 1365, 1369-70 (9th Cir. 1985) (holding that debt was bona fide because an independent lender such as a bank would be willing to make the loan); William T. Plumb Jr., The Federal Income Tax Significance of Corporate Debt: A Critical Analysis and a Proposal, 26 TAx L. Rev. 369, 530 (1971) (arguing that independent creditor's willingness to lend is the acid test of economic reality). Many start-up corporations cannot get loans from a bank or other thirdparty creditors. Testing whether a loan is bona fide is, however, a multi-factor test and some 32 factors have been identified as relevant. See id. Compensatory debt that is due without contingencies and which the parties enforce on its terms is probably bona fide debt if it is likely that payments can be made as due. There is, however, some tax risk of losing the deduction for interest for those companies that are not in a position to borrow. A finding that interest is not deductible will affect all of an issue and not just a marginal or excess amount of interest on the issue, but compensatory debt is issued in relatively small packages compared to total capital, and some compensatory debt might prove to be bona fide when issued, even when subsequent issues lose the interest deduction. 
debt, moreover, is nominal interest, which includes an amount to offset inflation. Deduction of the inflation element of interest is undoubted an error, as a matter of reasonable tax policy. The inflation element of interest is not a real cost to the debtor because it does not represent a reduction in cost-of-living terms. Inflation erases the burden of some of the nominal interest paid because the debtor gains from being able to pay the debt in cheaper, inflated dollars. ${ }^{19}$ In the 72 year period of the Ibbotson sample, the nominal interest on long-term corporate debt has been $5.7 \% .^{20}$ For much of the time of the Ibbotson data, the corporate tax rate has been above or near $50 \% .{ }^{21}$ A deduction of $5.7 \%$ nominal interest with a $50 \%$ tax rate saves tax of $2.85 \%$. When tax savings of $2.85 \%$, arising from a deduction of nominal interest, are subtracted from the real interest cost of $2.7 \%$, the after-tax cost of interest is negative $0.15 \%$. Negative real interest rates have persisted for long periods of time, ${ }^{22}$ which indicates the phenomenon is not ephemeral.

Negative after-tax, after-inflation interest rates for the corporate employer mean the issuer has no cost for deferring costs, but rather a reward. Compensation is cheaper for the employer the longer that payment is deferred. The $\$ 1000$ bonus to the employee shrinks in real terms over time if the bonus is given as debt. Considering the negative interest for the 72-year period of the model, the redemption price of a $\$ 1000$ bonus payable in debt is only $\$ 898 .{ }^{23}$ Considering the negative interest, the $\$ 203,000$ redemption price for the $\$ 1000$ stock bonus is not just thirty-three times more cash than debt, it is 226 times more expensive than stock for the same $\$ 1000$ value to the employee.

The higher redemption price for stock than for debt, in real terms, can also be translated into a smaller present value for the future cash that the corporation will pay. Stock requires a redemption payment that is 226

19. Including the inflation element within "interest" symmetrically means overtaxation of the creditor because the creditor is taxed on the "fool's profit" that just offsets the losses due to the shrinkage of buying power of the dollar. See, e.g., Daniel Halperin \& Eugene Steuerle, Indexing the Tax System for Inflation, in UNEASY COMPromise: Problems of a Hybrid Income-Consumption Tax 347 (Henry J. Aaron et al. eds., 1988).

20. See IbBotson Associates, supra note 13, at 102-105 (showing that 1925 dollar in long-term corporate debt grew to $\$ 55.38$ after 72 years). $\$ 1 *(1+i)^{72}=55.38$, where $i=$ $5.73 \%$.

21. See, e.g., Joseph A. Pechman, Federal Tax Policy 249 (5th ed. 1987) (showing in detail that corporate rates were near or over $50 \%$ in World War II and from 1953-1986).

22. Interest rates do not even keep up with inflation, ignoring the tax effects. See, e.g., Martin D. D. Evans, Real Rates, Expected Inflation, and Inflation Risk Premia, 53 J. FIN. 187,208 (1998) (explaining nominal interest's failure to keep up with inflation as indicating monetary fallacy that ignores changing real value of money). See also Eugene F. Fama, Term-Structure Forecasts of Interest Rates, Inflation, and Real Returns, 25 J. MONETARY ECON. 59 (1990) (stating that interest rates do not meet changes in inflation); Martin Feldstein, Inflation, Income Taxes, and the Rate of Interest: A Theoretical Analysis, 66 Am. ECON. Rev. 809, 816 n.15 (1976) (finding increases in interest rate that just match the increase of inflation, without regard to tax); Benjamin M. Friedman, Who Puts the Inflation Premium into Nominal Interest Rates, 33 J. FiN. 833 (1978) (finding an increase in bond yield of only $0.64 \%$ in response to a $1 \%$ increase in expected inflation).

23. $\left.\$ 1000 *[1+\mathrm{i}]^{72}=\$ 1000 * 1+(-.0015)\right]^{72}=\$ 1000 *(.9985)^{72}=\$ 897.55$ 
times more than the redemption payment for debt, given the assumptions, for the same $\$ 1000$ bonus. So it follows that stock gives the corporation a current value per dollar that the corporation must pay out eventually that is 226 times smaller than the credit the corporation will get for a dollar paid in redemption of debt. Debt gives the corporation more value for its money.

\section{Higher Return Corporations}

For the most successful companies, stock is even more expensive. The cost of debt does not go up for more successful companies. If anything, debt might drop below the average rate as a company proves its creditworthiness. The cost of stock increases, however, with success of the company. Small company stocks have given an average return of $9.3 \%$ per year in real terms over the seventy-two years of the Ibbotson sample. ${ }^{24}$ The average small company, under the sample, would need to redeem back its $\$ 1000$ stock bonus for $\$ 613,000$ in constant dollars, at the end of the term, or 100 times the cost of the debt, and the small corporation is getting present value credit for only $1 / 613$ of its future cash payment, or two-tenths of a penny per dollar paid. ${ }^{25}$ A corporation that does even better than average, say $12 \%$ growth for the sample, will need to pay back $\$ 3.5$ million in cash at the end of the term. ${ }^{26}$

\section{Current Conditions}

Under current conditions real interest rates on debt are positive, after tax, at least temporarily. From the end of 1994 to the end of 1997, corporate long term debt bore a real interest rate of $10.6 \%{ }^{27}$ and a nominal (deductible) interest rate of $13.4 \% .{ }^{28}$ Corporate tax rates have now dropped to $34-35 \% .{ }^{29}$ At those newer values, the real after-tax, afterinflation cost of interest is $5.9 \% .{ }^{30}$ Interest after tax and after inflation is not negative nor is it near zero. Debt, however, even though bearing positive interest, remains extraordinarily cheap compared to stock. Over the same period, large corporate stock has carried a time-value cost of $28 \%$. The $28 \%$ yield implies redemption costs of $\$ 52$ billion to redeem the $\$ 1000$ stock bonus, if current trends were to continue for 72 years. Fifty-two billion to redeem a $\$ 1000$ stock bonus is, of course, incredible, but it cannot be dismissed in full. A successful corporation issuing stock faces a meaningful risk of having the stock become very expensive.

24. See IbBotson Associates, supra note 13, at 104-105. $\$ 1 *(1+i)^{72}=613.46$, so $i=$ $\left({ }^{2} \sqrt{ } 613.46\right)-1=9.32 \%$.

25. $\$ 1 / 613=\$ 0.0016$

26. $\$ 1 *(1.12)^{72}=\$ 3,497,000$.

27. See lbbotson Associates, supra note 13, at 105 (showing a 1925 dollar invested in long-term bonds growing from $\$ 4.55$ to $\$ 6.155$ from the end of 1994 to the end of 1997 in constant-value dollars). $\$ 4.55^{*}(1+i)^{3}=\$ 6.155$, where $i=10.6 \%$.

28. See id at 103 (showing a 1925 dollar invested in long term corporate bonds growing from $\$ 38.012$ to $\$ 55.38$ in nominal terms). $\$ 38.012 *(1+i)^{3}=\$ 55.38$, where $i=13.36 \%$.

29. See I.R.C. $\$ 11$ (1998). Taxable income of over $\$ 10,000,000$ is taxable at $35 \%$.

30. $10.6 \%-(35 \% * 13.4 \%)=5.9 \%$. 
The premium cost of stock is part of a larger puzzle, which is that corporations in general seem to be relying too little on debt and too much on stock. Debt carries risks from the issuer's side because creditors can force payment, even if the payments force the corporation to sell core assets and liquidate the business. The impact of creditor remedies, however, should not be overstated. ${ }^{31}$ Rational creditors usually leave managers in place to salvage what they can from the assets, even in the case of bankruptcy. Corporations, moreover, are artificial entities and even liquidation or involuntary bankruptcy should not be confused with a lifethreatening event to an individual like starvation or physical injury. The largest corporations, with the most net worth, have the least chance of bankruptcy, and their considerable net worth after subtractions of liabilities indicates that they are not using enough debt to reach equilibrium. Most corporations stop using debt considerably short of the point where more debt might entail a material risk of bankruptcy, and they stop considerably short of the point where the value of the interest deduction might be imperiled because the corporation has no taxable income. ${ }^{32}$ Corporations should be issuing more debt overall, and less stock, including for the purpose of compensating employees.

\section{Explaining the Extraordinary Cost of Stock}

There are two plausible causes for the extraordinary discount rate on stock, relative to debt. Both are avoidable with rational compensation planning. Stock, first, is a lot more volatile than debt over short and medium time horizons. Investors, including executives, need to insist on a premium return to overcome their aversion to volatility. Stock, secondly, plausibly carries a premium in order to overcome investor distrust of management. Managers can divert undistributed funds to excess compensation or less profitable projects and investors react by discounting the future cash that the managers turn out in fact to make on the stock, at premium rates. Both volatility and management distrust can be avoided or reduced, however, in compensation planning. Issuers can avoid the premium discount rate and get more credibility for their future cash by switching over from stock compensation to debt or to deferred-cash compensation instead.

\section{Volatility}

Over a short or medium time horizon, stocks are much more volatile an

31. Cf. William A. Klein, High-Yield ("Junk") Bonds as Investments and as Financial Tools, 19 Cardozo L. Rev. 505 (1997) (arguing that risks to issuers and investors of junk bonds are overstated).

32. See, e.g., John R. Graham, How Big the Tax Benefits of Debt? Proceedings of the 91 st Annual Conference on Tax Held under the Auspices of the National TAx Association (forthcoming 1999) (finding that corporations issue too little debt to be explained by risks of bankruptcy or loss of tax-value). 
investment than debt. ${ }^{33}$ Holding stock tends to be like riding a roller coaster with dramatic swings in prices. Most of the volatility arises from factors outside the firm that executives can do nothing about.

Rational investors are risk-averse. Losses hurt an individual more than symmetrical gains help. Losses cut into muscle, and then bone, because they take away ever more desperately needed funds. Gains tend to add fat on top of current levels of consumption or standards of living. Executives have mortgage and tuition payments to meet, and they maintain a reasonably high standard of living that they would miss if compensation were lost. Executives, like other investors, dislike risk. If two investments have the same average yield and one is volatile in value while the other has a steady value, the volatile investment will be worth less. Investors also require a premium to overcome risk aversion as the volatility of investments increase, even if the expected or average outcome remains constant.

Most of the volatility of publicly traded stocks arises from factors which executives cannot influence. Stock prices go up or down largely because of market-wide or industry conditions that cannot be correlated with the separate performance of the individual firm. It is said that an average of $80 \%$ of variation in stock price for an individual firm is correlated with overall market movements or industry-wide price changes. ${ }^{34}$ Only $20 \%$ of the variation has something uniquely to do with the firm. To the extent that stock behavior is independent of the firm, it is also independent of the merits or control of the employee.

Making compensation benefit subject to stock price volatility, especially from causes outside the firm, adds an unnecessarily noxious factor to a compensation plan. As a matter of physiology, animals given electric shocks without being able to do anything about it show considerably greater distress than do animals who think they can do something to avoid the shocks. Executives who cannot affect the stock price are like "executive monkeys," yoked to shocks they cannot avoid. ${ }^{35}$ Even for corporate employers with stock that is increasing overall, price volatility is a

33. For a discussion of the short-term very high volatility of stock see RICHARD A. Brearly \& Stewart C. Myers, Principles of Corporate Finance 148-160 (5th ed. 1996). See also IBBorson Associates, supra note 13, at 112. See discussion accompanying infra note 39 to the effect that for long term investment, with a time horizon of over 20 years, diversified investments in stocks tend to be less volatile than investments in debt.

34. See Jeffrey Kerr \& Richard Bettis, Boards of Directors, Top Management Compensation and Shareholder Returns, 30 ACAD. OF MGMT. J. 645, 659 (1987). See also, Richard Roll, $R^{2}, 43$ J. Fin. 541, 558 (1988) (noting that the Wall Street Journal's mention of a company does not measurably affect that company's future stock price); See James J. Angel \& Douglas McGabe, Market Adjustments for Executive Compensation at 19 ( forthcoming 1999) (copy on file with SMU L. Rev.) (finding that $31 \%$ of variance of individual firm stock is explained by variance of stock market as a whole).

35. See J.V. Brady, Ulcers in Executive Monkeys, 199 SCI. Am. 469 (1958) (finding that monkeys who had no control over electric shock showed far higher physiological signs of distress than monkeys who were trained to avoid the shock and thought they could avoid shock); Gerald K. Weiss, et. al., The Effect of Two Different Types of Stress on Locus Coeruleus Alpha-2 Receptor Binding, 33 Brain Res. BULL. 219 (1994) (confirming the effect on mice). 
noxious element. Executives would be better off with a more consistent measure of their benefit, without regard to the level of their benefit.

Both executives and corporate employers would be better off without the volatility of stock prices, independent of the amount of compensation. Executives would be better off with a more consistent measure of their benefit than stock prices provide. Without the risk, executives would not need to demand the high discount rates that are applied to future cash to be distributed on stock. With lower discount rates, the corporation would get more present value for its future cash. At a minimum, it would yield a more efficient form of compensation if stock price volatility that is independent of the firm, were filtered out of the compensation. ${ }^{36}$ Even lower discount rates would be achieved, for the benefit of the corporate employer, if the corporation gave out debt as compensation instead of stock. As noted above, after-tax discount rates on debt have been trivial or slightly negative, on average over a long period of time.

Stock volatility alone does not explain the extraordinary discount rate on stock. In a recent review of the literature, Professors Jeremy Siegal and Richard Thaler showed that the premium on stock is far too high to be explained by risk. ${ }^{37}$ To explain stock returns, an investor would have to be so afraid of fluctuations that she would be willing to pay an insurance premium of $49 \%$ of her wealth just to avoid a $50 \%$ chance of losing half her wealth. ${ }^{38}$ That is too high a risk aversion to be plausible. The puzzle is deepened, Siegel and Thaler explain, because over extended periods of time, debt becomes riskier than stock. In a twenty year time horizon or beyond, Siegel and Thaler note, debt value is more volatile than stock value. ${ }^{39}$ Investors might also be afraid of catastrophic losses, Siegel and Thaler allow, except that it is debt rather than stock that has suffered the catastrophic losses in the past. Stock dropped precipitously, for example, in the great stock market crash of 1929. Truly catastrophic events, however, such as the German hyperinflation of the 1920s or the Japanese hyperinflation after World War II, effected debt, not stock, and wiped out the value of debt holdings altogether. Nothing in any stock market has been as bad.40 Finally, Siegal and Thaler try to explain only the pre-tax disparities in compensation due to differences between the

36. See Rick Antle \& Abbie Smith, An Empirical Investigation of the Relative Performance of Corporate Executives, 24 J. AcCr. REs. (1986) (arguing that taking systematic risk out of stock volatility reduces risk to executives).

37. See, e.g., Jeremy J. Siegel \& Richard H. Thaler, Anomalies: The Equity Premium Puzzle, J. Econ. Persp., Winter 1997, at 191; Narayana R. Kocherlakota, The Equity Premitum: It's Still a Puzzle, 34 J. Econ. Literature 452 (1996); Andrew B. Abel, The Equity Premium Puzzle, Bus. Rev.: Fed. Res. Board of Philadelphia 3 (Sept./Oct. 1995). The seminal article on the subject is Rajnish Mehra \& Edward C. Prescott, The Equity Premilum: A Puzzle, 15 J. Monetary Econ. 145 (1985).

38. See Siegel \& Thaler, supra note 37, at 192 (citing Mehra \& Prescott, supra note 37).

39. See Siegel \& Thaler, supra note 37 , at 195 . The volatility of a diversified stock portfolio decreases as time goes by because fluctuations in the value of the portfolio tend to offset each other. The volatility of debt, by contrast, increases over time because inflation affects the value of the debt.

40. See id. at 194. 
returns on stock and on debt. After-tax disparities between the returns on stock and on debt are even more extreme ${ }^{41}$ and hence even less likely to be explained fully by risk. Thus the extraordinary discount rate on stock needs to be explained by factors in addition to volatility.

\section{Agency Explanation}

An additional factor that plausibly helps to explain the high discount rate on corporate stock is investor distrust of management. In theory, assets within a corporation are ultimately owned by shareholders, as if the assets were part of the shareholder's wealth or bank account balance, which are earning extra income for the shareholders. In the large corporation, however, managers control the assets that shareholders purport to own, and shareholders cannot assume that management will use the assets loyally to maximize shareholder value. The shareholder's primary remedy giving value to corporate stock is that distributions must be made pro rata to shares within the same class of stock. That remedy, however, does not prevent management from withholding distributions and using undistributed corporate wealth in ways that the shareholders do not participate in, or making corporate investments that do not maximize shareholder value. ${ }^{42}$

Management self-interest gets in the way of loyalty to the shareholders. Management can and does pay itself excessive compensation. ${ }^{43}$ Management can be, and often is, overindulgent in paying for office privileges and perquisites. ${ }^{44}$ Management tends to receive higher compensation in

41. See discussion in text accompanying supra notes 18-22. See also Calvin H. Johnson, Equity Premium Puzzle, J. Econ. Persp., Fall 1997, at 233.

42. The literature on conflict between management and shareholder interests of a corporation goes back to Adolf A. Berle, Jr. \& Gardiner C. Means, The Modern CorPORAtion and Private Property (1933) (stating that management tends to engage in activities that are harmful to shareholders, such as excessive retention of earnings and executive compensation) and Michael C. Jensen \& William H. Meckling, Theory of The Firm: Managerial Behavior, Agency Costs and Ownership Structure, 3 J. Fin. Econ. 305 (1976).

43. Executive compensation is too high, whether judged by historical standards or by the norms set by our trading partners and competitors. Graef Crystal points out, for instance, that American chief executive officers are paid 120-150 times the average wages of workers, whereas comparable Japanese CEOs are paid 16 times the wage of workers. As late as 1974, the salary of American CEOs was only 35 times an average worker's wage. In 1990 , the average salary for the CEO of a United States public company was $\$ 2.8$ million and the average for a CEO of Japanese company was $\$ 310,000$ (about $1 / 9$ of the U.S. CEO's wage). See Graef S. Crystal, In Search of Excess: The Overcompensation of American Executives 23-28 (1991). See also Derek Bok, The Cost of Talent: How Executives and Professionals are Paid and How It Affects America 95, 297 (1993) (doubting that mind-numbing levels of executive pay properly allocate talent in a manner that corresponds to America's needs and goals); George F. Will, Ripping Off Capitalism, WAsH. Post, Sept. 1, 1991, at C7 (claiming that "ludicrous" CEO salaries are sometimes "looting"); Peter F. Drucker, Is Executive Pay Excessive?, Wall St. J., May 23, 1977, at A-20 (proposing to limit CEO pay to 20 times worker's pay).

44. For a wonderful illustration, see Bernie Shellum, Fruehauf Steers into Trouble: Management Cited in Decline of Truckmaker, CHI. TRIB., Feb. 27, 1989, at C1 (reprinted in Ronald Gilson \& Bernard Black, The Law \& Finance of Corp. Acquisitions 363 (2d ed. 1995) (reporting that management destroyed historical industry leader with extravagant extras and golf)). 
larger corporations, so management tends to hold on to earnings to make the corporation larger, even when distribution of the earnings would improve shareholder wealth. ${ }^{45}$ Management has a bias in favor of plowing earnings back into the industry with which they are familiar, even if that is not the best available investment, because that increases management competence and security. ${ }^{46}$

Shareholder remedies are too weak to prevent managers from paying themselves too much or from making sub-optimal investments. In large corporations, there are too many shareholders with too little at stake to make it worth the considerable cost of testing the quality of management. Independent shareholders do not know how to improve the business or investment judgment of their managers, nor do they know how to improve management business performance. Even if they did know, their small stake would not make it worthwhile to undertake a campaign to replace management. In large corporations, shareholders are owners only in theory, and in reality management appoints the board of directors. In the modern, publicly held corporation, shareholder votes and other remedies are not strong enough to ensure that managers are loyal to the shareholders. ${ }^{47}$

Shareholders respond to the weakness of their control over their agent managers by discounting the price they are willing to pay for their shares on the market. A discount rate for future cash, reflected in the extraordinary premium return on stock, is mathematically equivalent to a low price paid for the stock. Given the extent of management's ability to loot the corporation or to make bad investments, outside shareholders with no reliable information or control are forced to assume that the shares are

45. See, e.g., Joseph W. McGuire et al., Executive Incomes, Sales and Profits, 52 AM. Econ. REv. 753, 760 (1962) (finding that executive compensation increases as gross receipts increase); Henry Hansmann, The OWnership of Enterprise 37 (1996) (arguing that management opportunism works most easily by excessive retention of earnings).

46. See, e.g., Andrei Shleifer \& Robert W. Vishny, Management Entrenchment: Firm Specific Investment, 23 J. OF FIN. ECON. 123 (1989) (arguing that management plausibly makes investments in area of their expertise to make themselves indispensible).

47. Some have argued that the hostile takeover is the best current remedy for managers who loot the corporation or make sub-optimal investments. An outside raider will be able to offer a price for shares higher than the current stock price because the raider is confident that he can improve the return on the target's assets simply by replacing current management and making better use of corporate resources. See Henry Manne, Mergers and the Market for Corporate Control, 73 J. Pol. Econ. 110, 113 (1965); Ronald J. Gilson, A Structural Approach to Corporations: The Case Against Defensive Tactics in Tender Offers, 33 Stan. L. REv. 819, 841 (1981). The takeover remedy may lead to local improvement, however, while making the global situation much worse. Takeovers make corporations larger, and larger corporations are even less responsive to shareholders than smaller corporations. Managers of larger corporations have a more protected position from which to loot the corporation via excessive salaries and bad investments because it is harder to organize shareholders or take over the corporation the larger the corporation grows. Cf. Andrei Shleifer \& Robert W. Vishny, Value Maximization and the Acquisition Process, 2 J. Econ. Persp. 7, 15 (1998) (arguing that takeover of other companies at inflated prices may be the greatest deviation by management from stockholder wealth maximization). 
"lemons." 48 The low price that the market places on shares is the revenge that shareholders visit upon the corporation for the self-interested behavior of its management.

The best evidence that the high discount rates on stock are caused, at least in part, by distrust of management is that management can increase the stock price by paying out more dividends, even though dividends are not the best option from a tax planning perspective. As a matter of tax alone, dividends hurt individual shareholders and should reduce the price of stock. Dividends are ordinary income, currently taxed at rates as high as $44 \% .{ }^{49}$ Accumulated earnings are capital gains to the shareholders, taxed only if there is a sale before death and bearing a tax of from zero to $20 \% .{ }^{50}$ For much of the seventy-two year sample, dividends have been taxed at $50 \%$ to $70 \%$. Shifting from zero to $70 \%$ tax for corporate earnings by paying a dividend should reduce the value of the earnings by over three times, to $30 \%$ of pre-dividend value.

Nonetheless, the non-tax value of dividends, in overcoming the agency problems with accumulated earnings, more than offsets the considerable tax effect. Dividends give the shareholders a "bird in the hand." The earnings of the corporation are then no longer subject to management looting. Management usually claims that the corporation's stock is undervalued-much as grandparents claim the beauty of their grandchildren-but dividends are more credible to shareholders than managers' words. Dividends give shareholders control of the money and provide credible evidence that the corporation is prospering. Reducing the dis-

48. George A. Akerlof, The Market for "Lemons:" Quality Uncertainty and the Market Mechanism, 84 Q.J. ECON. 488 (1970) (arguing that markets are destroyed when buyers have inaccurate information because they have to underbid for assets on the assumption that the asset is as bad as it could be); Hayne E. Leland \& David H. Pyle, Informational Asymmetries, Financial Structure, and Financial Intermediation, 32 J. FIN 371 (1977) (arguing that information asymmetry will drive down the price of stock and prevent a corporation from using stock to fund projects with positive value); P.K. Chauncey \& C.M. Lewis, Earnings Management and Economic Information, 1 J. CoRP. FIN. 319 (1995) (applying the "lemons" argument to share valuation under bad accounting information).

49. See I.R.C. $\$ 1$ (a)-(d) (1998). The statute provides for tax rates on individuals of up to $39.6 \%$ while I.R.C. $\$ \$ 68,151$ (d)(3) add complicated "phase out" surcharges that bring the marginal tax rate up to $44 \%$, for a family of husband and wife and two children. See Calvin H. Johnson, Simplification: Replace the Personal Exemptions Phaseout Bubble, 77 Tax Notes 1403, 1404 (1997). The largest phase-out tax, for personal exemptions, typically lasts from $\$ 187,00$ to $\$ 309,000$ of taxable income and tax rates drop down to $41 \%$ for incomes above the phase-out range. See Rev. Proc. 97-57, 1997-52 I.R.B. 20.

50. See I.R.C. $\$ \$ 1(\mathrm{~h})(1)(\mathrm{E}), 1222(3)$, (11) (1998). The statutes provide for a maximum tax of $20 \%$ on "capital gain." "Capital gain" arises because the corporation accumulates its earnings, rather than distributing them as dividends, or because the future prospects of the corporation turn out to be better than expected. Capital gain that accrues, but is not realized or taxed before the death of the owner of the shares is never taxed. See I.R.C. $\$ 1014$ (1998) (providing that the basis of property acquired from decedent is the fair market value at the date of death, rather than decedent's cost). The combination of low nominal rate, deferral of imposition of tax until sale and forgiveness of tax upon death typically reduce the expected tax rate on capital gains to under $10 \%$. See Calvin H. Johnson, The Undertaxation of Holding Gains, 55 TAX NoTEs 807 (1992). 
trust overcomes the tax effect. ${ }^{51}$ Dividends reduce investor distrust enough to overcome the tax effects, so that dividends do not reduce the value of the stock overall 52 and can actually increases the value of the stock on the market! 53 The price increase for corporate action that increases shareholder tax is the best evidence that distrust of management causes the extraordinary stock premiums.

Consistently, increasing the firm's debt increases the value of the firm, although for debt the cause is more ambiguous. Debt provides a credible promise by management to pay interest as it is due, replacing the less credible rules for distributions on stock. Debt forces management to distribute cash as the interest and principal of the debt become due. Further, debt provides a credible signal that the firm is not worried about bankruptcy and is willing to go to the capital market. Increasing the ratio of debt to equity in the corporation increases the value of the corporation. 54

For debt, the increase in share value, caused by more debt, cannot be unambiguously attributed to an increase in management credibility because tax effects might also explain why increasing debt increases share value. For short-term investments, more debt might increase the value; considering only the tax, but for very long-term investments by share-

51. See Morton H. Miller \& Kevin Rock, Dividend Policy under Asymmetric Information, 40 J. FiN. 1031 (1985) (arguing that corporations need to make dividends to signal success even if that means that they forego opportunities with positive value); Andrei Shleifer \& Robert W. Vishny, A Survey of Corporate Governance, 52 J. Fin. 737 (1997); Sudipto Bhattacharya, Imperfect Information, Dividend Policy, and the "Bird in the Hand" Fallacy, 10 BELL J. ECON. 259 (1979) (arguing that tax cost to dividends make the signaling effect credible); Larry H.P. Lang \& Robert H. Litzenberger, Dividend Announcements: Cash Flow Signaling vs. Free Cash Flow Hypothesis, 24 J. Fin. ECon. 181-91 (Nov.-Sept. 1989).

52. See Eugene F. Fama \& Kenneth R. French, Taxes, Finance Decisions, and Firm Value, 53 J. FIN. 819 (1998) (showing the positive value that dividends serve by giving reliable information completely masks the tax effect, so that there is no hint of tax reducing value). Cf. Kathryn L. Dewenter \& Vincent A. Warther, Dividends, Asymmetric Information, and Agency Conflicts: Evidence from a Comparison of the Dividend Policies of Japanese and U.S. Firms, 53 J. Fin. 879 (1998). (Japanese firms face less need to distribute dividends to provide creditable information to owners because Japanese firms have closer ties to creditors and owners).

53. See Paul Asquith \& David W. Mullins, Jr., The Impact of Initiating Dividend Payments on Shareholders' Wealth, $56 \mathrm{~J}$. Bus. 77 (1983) (showing that announcements of increased dividends increase stock price); Kose John \& Joseph Williams, Dividends, Dilution, and Taxes: A Signalling Equilibrium, 40 J. FIN. 1053 (1985) (showing that announcing a dividend will increase the value of stock). See also Tom Nohel \& Vefa Tarhan, Share Repurchases and Firm Performance: New Evidence on the Agency Costs of Free Cash Flow, 49 J. FIN. ECON. 187 (1998) (showing that stock repurchases increase share value, not by signaling greater performance, but by disgorging cash that the corporation can not profitably invest).

54. See Michael C. Jensen, Agency Costs of Free Cash Flow, Corporate Finance, and Takeovers, 76 AM. ECON. REv. 323 (1986) (arguing that increasing leverage increases the value of stock by forcing management to disgorge cash to shareholders if they do not have corporate investments that improve net present value of the firm); JAMES C. VAN HORNE, Financial Management and Policy 285 (10th ed. 1995) (stating that debt increases the value of the firm by signaling that managers do not fear bankruptcy); Stephen A. Ross, The Determination of Financial Structure: The Incentive-Signaling Approach, 8 BELL J. ECON. 23 (1977) (finding that value increases as debt increases). 
holders, under current tax rates, less debt would increase the value of the firm. ${ }^{55}$ Given that more debt might improve value for tax purposes, an increase in value of the firm when debt increases cannot be unambiguously attributed to a decrease in distrust of management. The data, however, is consistent with the theory that shareholder mistrust depresses the value of stock.

The agency theory for high discount rates on stock plausibly explains why stock does not reach equilibrium with debt and why issuers do not replace high-cost stock with other forms of paying compensation. Management could increase the value of shareholder interests by issuing debt or dividends, but debt or dividends would reduce the accumulated earnings under management control. Management often wants to retain earnings to feather its own nest. Management also wants to pay for its perquisites and excessive compensation and make self-aggrandizing investments. Stock is a very expensive way for the issuer to pay cash and remains more expensive than debt, but management is disloyal to the issuer. To reach an equilibrium between debt and stock, management would have to work in favor of shareholder interests and against its own interests.

The theory that stock is undervalued because the corporation pays out more cash than shareholders can reliably predict beforehand implies that management can make matters worse by reducing the quality of information given out to shareholders. Compensatory stock options given to management, for example, are not reported as part of the earnings reported to shareholders. ${ }^{56}$ Shareholders get revenge for vague and misleading accounting by increasing the discount rate reflected in the price for the stock. Obfuscation and dishonesty reduce the value of stock. Countries that do not provide outside investors with significant information do not have public markets from which firms can raise money. ${ }^{57}$ The costs of lying or providing vague information to the market may be dif-

55. Assume that a corporation is considering whether to buy back $\$ 1000$ of stock in return for $\$ 1000$ of debt from a shareholder who has just purchased the stock who and can, therefore, sell it back without taxable gain. Assume also that the corporation will redeem the debt (or stock) in year $n$. The shareholder should sell the stock, increasing the corporation's debt, if debt gives a higher terminal value at $n$ and should hold the stock if stock gives a higher terminal value at $n$. The terminal position with debt is $\$ 1000^{*}\left[1+I^{*}\left(1-T_{s}\right]^{n}\right.$ where $T_{\mathrm{s}}$ is the shareholder's tax rate, and $I$ is the interest rate. The terminal position with stock, assuming accumulation of all earnings and a capital-gain redemption at the end, is $\$ 1000 *\left[1+R^{*}\left(1-T_{\mathrm{c}}\right]^{\mathrm{n}} *(1-\mathrm{cg})\right]+c g * \$ 1000$, where $R$ is the return to the corporation, $T_{\mathrm{c}}$ is the corporate tax rate, and cg is capital gains tax rate. The final " $c g^{*} \$ 1000$ " term reflects the fact that the basis is subtracted to compute gain and is not subject to capital gains tax. See Myron S. Scholes \& Mark A. Wolfson, Taxes and Business Strategy: A PlanNING APPROACH 57-58 (1992). With $I=R=10 \%, c g=20 \%, T_{\mathrm{c}}=35 \%, T_{\mathrm{s}}=44 \%$, the break-even $n$ is in the forty-fifth year, so with $n<45$ years, debt is more valuable. If $n>45$ years or if capital gain drops down to zero because of death, then stock is more valuable for the highest taxed individual.

56. See Accounting for Stock-Based Compensation, supra note 12.

57. See, Johnson, Accounting in Favor of Investors, supra note 12, at 638 (arguing that countries that do not provide outside investors with accurate information do not allow companies to raise significant capital from public markets): Shleifer \& Vishny, supra note 51 , at 5 (discussing countries where capital markets are well-developed and poorly devel- 
fused to all firms, while the benefit of the lie may rebound to the scoundrel. Still, anything that decreases firm credibility increases the discounts reflected in their shares.

In sum, debt is cheaper for the issuer in part because the corporate obligation with debt is more credible. When after-inflation and after-tax discount rates are near zero, as they have been over long periods of time, the market will not discount the future dollar the employer pays by any material amount to determine present value. By contrast, when the corporation gives cash by way of stock the market insists that the corporation pay out $7.7 \%$ after inflation because the expectation of cash is less reliable. The present value of the cash payable in 72 years shrinks to a trivial level of one-half of a cent for every dollar the corporation ultimately pays. ${ }^{58}$ The market value gives the corporate issuer too little credit for the real value of cash it will ultimately pay on stock.

\section{STOCK COMPENSATION IS MORE EXPENSIVE THAN CASH DEFERRED COMPENSATION}

Stock also competes with deferred compensation payable in cash as an alternative way to pay future cash. Deferred compensation is almost always the better alternative. Stock is often touted as a way to give management proper incentives, but cash plans are flexible and can avoid the incentive distortions inherent in stock and stock options. Cash is also cheaper than stock, for the same amount of future cash, because deferred compensation can increase the issuer's credibility and decrease the issuer's discount rate. Finally, stock is often touted as a way to give employees capital gain, but there is a tax theorem, with wide applicability, that deferred cash compensation gives the employee the same after-tax benefit as if there were no tax on capital gain.

\section{A. InCENTIVES}

Stock compensation is said to be useful as an incentive device to align an executive's self interest with the interests of the shareholders. If management has a meaningful percentage of total corporate equity, then that is said to provide a "direct and powerful "feedback effect." 59 Some say that with stock compensation, executive incentives and shareholder interests will converge. ${ }^{60}$ Moreover, if top managers are willing to invest in the corporation or corporate projects with their own money, that sends a

oped because of protection of outside investors). See also, Akerlof, supra note 48, at 488 (arguing that there is economic cost to dishonesty).

58. See text accompanying supra notes $14-23$ for a more complete explanation of this model and assumptions.

59. Michael C. Jensen \& Kevin J. Murphy, CEO Incentives-It's Not How Much You Pay, But How, Harv. Bus. Rev., May-June 1990, at 138, 141.

60. See Mark J. Loewenstein, Reflections on Executive Compensation and a Modest Proposal for (Further) Reform, 50 SMU L. REv. 201, 206 (1996). 
powerful signal to the market that the corporation is a good investment. ${ }^{61}$

Stock compensation, however, turns out to be a very poor instrument to give management the proper incentives. The incentives are ineffective, go awry, or are delivered inefficiently. Anything stock can do cash can do better.

\section{Drawbacks of Stock as an Incentive Device}

Stock cannot ensure management loyalty to shareholders, first, because management can own only a fraction of the stock. Assume, for example, that a chief executive officer (CEO) owns $5 \%$ of the stock of a publicly owned corporation, which is a very high percentage under current norms. ${ }^{62}$ The stock ownership would be insufficient to prevent the CEO from being disloyal to shareholders when there is a direct conflict between the CEO's and the shareholder's interests. Assume, for example, that the $\mathrm{CEO}$ is considering paying herself excessive compensation. The CEO gets $100 \%$ of the excessive compensation in her role as recipient of the compensation. She loses $5 \%$ of the payments in her role as shareholder of the corporate employer. For every dollar of excess compensation she pays herself, she is ninety-five cents ahead. There may be some fringe benefits and perquisites of office that give the CEO a value of less than five cents per dollar of corporate cost. For those, her ownership of stock would make her realize that such a perquisite was not a free lunch and she would stop it. The limitation, however, is not very important at the level of ownership that managers of public corporations have. If, for instance, a perquisite of office gives six cents of value per dollar of corporate cost, she would be better off with the perquisite than without it, even given the damage to her share value. A manager of a publicly held corporation cannot own $100 \%$ of the shares, by definition, and so her shareholdings cannot prevent self-interested behavior that hurts the value of those shareholdings. Relying on shareholdings to control management misbehavior provides false security.

Large stock holdings can distort incentives, for instance, by making management too conservative. Rational shareholders usually want management to ignore the risks to the business that the shareholders can avoid by diversification. ${ }^{63}$ Rational investors diversify their portfolios because many of the risks of any particular stock are firm-specific and can be offset by fluctuations in other investments that move, as sine and cosine curves do, so as to cancel out the risks. A shareholder can blithely

61. See Leland \& Pyle, supra note 48 , at 372 (arguing that the best signaling by managers is their willingness to undertake investments in their firm's projects with their own money).

62. See Clifford Holderness, Were the Good Old Days that Good? Changes in Managerial Stock Ownership Since the Great Depression, NBER WorkING PAPERS No. 65501 at 9 (1998) (reporting that the top corporate officer holds an average of $1.25 \%$ of corporation's stock and that the percentage has been steady since the data series began in 1935).

63. See, e.g., Henry T.C. Hu, Risk, Time, and Fiduciary Principles in Corporate Investment, 38 UCLA L. Rev. 277, 319-320 (1990); Bernard S. Black, Bidder Overpayment in Takeovers, 41 Stan. L. Rev. 597, 624 (1989). 
disregard diversifiable risks. For example, if only one of three companies will get a big contract, an investor can avoid bearing the damage from loss of the contract by owning stock of all three companies. Large block holdings by management, however, are too big for the firm-specific losses to be diversified away. Management will then avoid the firm-specific risks that would have been avoided by diversification even for investments with an expected positive value because the loss hurts them too much if it happens. Management already tends to be too conservative because their livelihood is invested in the firm and cannot easily move to another company. Large stock holdings push management to be even more conservative. ${ }^{64}$

Stock performance is also an inferior incentive for good performance by an executive because stock price has a high level of volatility that an executive cannot control. It has been estimated, as noted, that $80 \%$ of the volatility of stock prices arise from forces that are not individual to the firm. Volatility from factors outside of the firm add random shocks to compensation, punishing the just and rewarding the incompetent. With stock-based compensation, incompetent or disloyal managers will profit from a rise in stock price that he or she did not affect. Capable and loyal managers will be hurt if the stock price declines for reasons that have nothing to do with their performance.

\section{Stock Option Distortions}

Giving stock options to management is one of the most popular forms of stock compensation because the employer's cost of compensation does not have to be reported on public financial statements. ${ }^{65}$ Stock options, however, create truly bizarre incentives for management to squelch dividends and seek out risk, even though it damages shareholder wealth. Stock options give management an incentive to accumulate earnings rather than distribute them because accumulated earnings increase the value of stock options by increasing the value of the stock and the bargain that the option holder will achieve. Stock options do not, however, participate in dividends. Stock options encourage management to go into very high risk investments that have negative expected value because the holder of an option participates in the gains in value, but not the losses.

Assume, for example, a model with the following facts: The chief executive officer and top management of Widget Corp. have options to purchase $5 \%$ of Widget stock at the current fair market value one year hence. Widget's net assets are worth $\$ 100$ million and Widget has no debt. Widget Corp. has an opportunity to go into a start-up business by investing its $\$ 100$ million worth of assets. The new opportunity has a $10 \%$ chance of being worth $\$ 900$ million after one year and a $90 \%$ chance of being worth nothing. Generally, available no-risk investments give a return of $6 \%$. The opportunity has a negative expected value because the

64. See Hu, supra note 63 , at $327-329$.

65. See Accounting for Stock-Based Compensation, supra note 12. 
$10 \%$ chance of making $\$ 900$ is worth $\$ 90$ million and $\$ 90$ million discounted by one year at $6 \%$ is $\$ 84.9$ million. Investing $\$ 100$ million for an expected return of $\$ 84.9$ million is a losing strategy from the shareholder point of view.

The high-risk, $90 \%$-failure, negative-expected value start-up business is rational from the managers' private point of view, however, even though it hurts shareholders, because the managers hold stock options. Managers do not participate in the shareholder's loss in the $90 \%$ of the time that the start-up fails. If the start-up fails, they just fail to exercise their option so that they have neither gain nor loss. In $10 \%$ of the cases in which the start-up succeeds, however, an option for all of the stock (exercisable at current fair market value) will be worth ( $\$ 900$ million- $\$ 100$ million.) * $10 \% /(1+6 \%)$ or $\$ 75.47$ million. Management has the option of acquiring only $5 \%$ of the corporation. Their options will thus be worth only $5 \%$ of the $\$ 75.47$ million. Still, management gets positive value from its stock options if the investment made, making the risky start-up investment beneficial to management considering only their own selfish position.

Now assume that the corporation has earnings of $\$ 10$ million, which can either be distributed as a dividend or invested internally in a project worth only $\$ 8.49$ million. With loyalty to the shareholders, management would distribute the $\$ 10$ million now, rather than the $\$ 8.49$ million when the project is complete. Management with stock option, however, will get no value reflected in their option if the $\$ 10$ million is distributed immediately. If they follow their self interest, they will accumulate the money in derogation of the shareholder's interests.

Stock option plans are also usually too rigid even to be adapted to measures of executive performance. Stock option plans that rely on avoiding treating the option as a cost in published financial statements, for instance, must fix the exercise price of the option and the number of shares at the time the option rights are granted. ${ }^{66}$ If either exercise price or shares subject to the option are changed, that creates a new measurement date. If the stock has appreciated since the option was granted, that means that the employer will not have a zero reported cost for the compensatory option, but rather a cost measured by the difference between the value of the stock and exercise price as of the new measurement date. The employer can then no longer rely on the absence of a bargain on the option using the fair market value of the stock when the option was originally granted. In order to avoid reports to shareholders of the compensation cost of a stock option, the corporation must bind itself in ways that can get in the way of optimal compensation design.

In the abstract, it might be possible to use stock and stock options as part of a mix to create incentives for management that perfectly offset the other biases of management. ${ }^{67}$ Cash plans, however, give the employer

66. See Accounting for Stock-Based Compensation, supra note 12, II 5 (allowing continuation of Accounting Principles Board No. 25, II 10b).

67. See Hu, supra note 63, at 325 n.126. 
the flexibility that a fixed exercise price and fixed amount of stock do not have, making it easier to create the optimal incentives.

\section{Incentives with Deferred Payment of Cash}

Any incentives for the employee that stock compensation provides can be duplicated and improved with a cash plan. If employees are paid cash under a deferred compensation agreement, the contingencies for paying cash can be set with flexibility and intelligence. A cash deferred compensation plan could mimic the rewards of stock compensation if that were helpful. "Phantom Stock" and "Stock Appreciation Rights," for instance, are plans that pay the employee cash for the increase in the price of the employer's stock as if the employee owned the shares for some period of time. ${ }^{68}$ The employee is given units of his employer's stock, purely on paper, and gets paid the appreciation in value of those shares in cash, without ever becoming a real shareholder or having to come up with the capital for the initial purchase price. If measuring appreciation by stock value were a virtue, then a cash plan could capture the virtue without committing the employer to the extraordinary cash, discounted at extraordinary rates, that a stock issue requires. Cash distributed from Phantom Stock plans, moreover, may be deducted for tax purposes; distributions of the same amount of cash to the employee on real stock may not be deducted for tax purposes.

Customizing a cash deferred compensation plan can cure some of the faults of stock compensation even if stock performance is the core underlying idea. Phantom Stock, which pays management when dividends are paid, is better than Stock Appreciation Rights in reducing management's incentive to retain corporate earnings. A cash deferred compensation plan can screen out some of the factors over which the employee has no possible control. The contingency for payout could, for example, have subtracted from it a general index of all stocks on the stock market so that economic conditions affecting the whole stock market would not affect compensation. ${ }^{69}$ For that matter, once the parties understand the flexibility, employees might be paid upon contingencies that are more responsive than overall stock prices to employee production or merit. A division chief, for example, might be rewarded under an internal control system that better describes the performance of the division than do company-wide earnings or overall corporate stock performance.

68. See, e.g., Phantom Stock Not a Second Class of Stock, 78 TAx Notes 431 (1998) (describing I.R.S. Private Letter Ruling 9803023 as saying that phantom stock is not included in employee's income until paid); James Hamill, Nonqualified Stock Plans Can Be Adapted to Meet the Needs of Privately Held Companies, 82 J. TAx. 100 (1995). 'Stock Appreciation Rights' tend to give the employee only the value of the increase in price of shares. 'Phantom Stock' tends to give the employee cash as well when dividends are paid on the real stock. Id.

69. See Angel \& McGabe, supra note 34, at 19 (arguing that general market volatility needs to be filtered out of executive compensation measures). 
One of the benefits of stock for the employee is that the employer is pre-committed to giving the employee the future gain on the stock and future cash flows on the stock. With discretionary bonuses awarded after employee performance, the employee properly fears that the employer can behave tactically and pay the employee less than she was expecting. A pre-commitment would assure the employee that effective work will be rewarded. Deferred cash compensation, however, can be pre-committed to the employee with a clear, objective set of conditions for payout. Anything that stock can do, cash can do better.

Cash compensation, moreover, forces the employee to evaluate the cost of the compensation. Plans that pay out cash at the end may not be treated as cost-free for financial accounting purposes, even if they mimic stock option plans. As compensation is earned by the employee, it is accrued as an expense by the employer. ${ }^{70}$ If the employer budgets internally from accounting books that include the compensation, the cost to the employer will be understood-perhaps the move to cash plans will force the employer to understand the cost of the compensation for the first time. Once understood, cost can be controlled and shaped to do the most good per dollar spent. There seems to be a fallacy that stock is free to the employer-that the employer prints its own stock. ${ }^{71}$ Everyone, however, understands the cost of real cash. Understanding the real cost of compensation is the first step to getting the cost under control.

\section{B. Reducing The Discount Rate}

Deferred compensation should be cheaper than stock for giving any benefit to an employee, because deferred compensation can drop the discount rate at which the employee evaluates the value of the future cash without dropping the discount rate which the employer uses to evaluate its cost. For a corporation that can make good profits from its business activities, there is an asymmetry of discount rates available under which the employee values the future cash highly, in present value terms, whereas the employer finds it very cheap to fund, in present value terms.

\section{The Value of an Enforceable Promise}

Switching from stock compensation to deferred cash will make compensation more efficient by reducing the discount rate recipients use to discount cash that will be paid in the future. Deferred compensation plans represent a promise to pay the employee, which the employee may enforce in a court of law. The promise of cash is more credible for the employee. Stock entails no promise to pay at any time, and the shareholder may not force payments or prevent self-interested management behavior as to accumulated earnings. Deferred compensation may be

70. See, e.g., AcCounting for Stock-Based Compensation, supra note 12, 925 (stating that corporations accrue cost of a Phantom Stock plan according to fair market value of stock at end of accounting period).

71. See text accompanying supra note 11. 
payable under a formula that has unknowns in it, such as stock price or earnings of the division, but the formula at least gives the promise of a payout, determinable from objective criteria at a time certain. Unknowns in the formula, however, will probably prevent the discount rate on deferred compensation from dropping into the range of that on debt. Employees will probably never evaluate deferred compensation with a negative after-tax discount rate that has applied to debt. Deferred compensation, however, will reduce the discount rate used in the calculation of present value, by cutting down on management opportunities for selfserving future behavior at the expense of the recipient. Deferred compensation has every promise of reducing the distrust about future management which creates such extraordinary discount rates with respect to stock.

Reducing the discount applied to future cash by the employee would have no effect on the return on investments that the employer uses to fund future cash and to compute its current cost. A corporate employer with an extraordinary $12 \%$ or $20 \%$ after-tax return rate on its investments has committed a fraction of that return by giving out stock. It can use the same extraordinary rate on investments to fund future deferred compensation, without necessarily committing cash payments that increase at $12 \%$ or $20 \%$ per year over time. Switching from stock to cash should increase the value of the compensation to the employees without increasing the cost to the employer.

\section{Rabbi Trusts}

It is also possible to increase credibility of future management even more by setting up what is known as a "rabbi trust." A rabbi trust is an irrevocable commitment of funds for the benefit of the employee. The employer can not reach the trust funds. The trust remains subject to the claims of creditors of the employer and the employee has no preferred claim in bankruptcy. The Internal Revenue Service will rule that the employee has no taxable compensation until the cash is paid out. ${ }^{72}$ A major cause of the extraordinary discount rates on stock appears to be distrust of opportunistic behavior by management in the future. The rabbi trust cannot protect the employee from managers who drive the employer into bankruptcy; but, if the employer does not go into bankruptcy, the rabbi trust can ensure that there is a fund of money to pay the employee under the deferred compensation plan. Another major cause of the extraordinary discount rate on stock is volatility of the price of stock. A rabbi trust can invest in low volatility or high volatility investments with unfettered choice.

72. See Rev. Proc. 92-64, 1992-2 C.B. 422 (explaining that the I.R.S. will issue a ruling that an employee does not have taxable income from a rabbi trust, provided the trust is subject to claims of creditors and that it gives the employee no priority interest); Priv. Ltr. Rul. 81-13-107 (Dec. 31, 1980) (holding that a synagogue could set up a trust for its rabbi without the rabbi being taxed). 
Putting funds into a rabbi trust, however, would plausibly have a detrimental effect on the employer-side discount rate. Funding means that the trust would have to invest in publicly available investments and publicly available investments can be expected to give only an average rate of return for the risk. Extraordinary returns are available to any corporate employer only because capital is combined with entrepreneurial skill or position. If funds are put into a rabbi trust by a corporation that can make better than publicly available returns, the funds should plausibly be re-lent out to the corporation for use in the business. A loan between a rabbi trust and the employer is invisible for tax purposes, ${ }^{73}$ but it affects a real transfer of cash from outside the irrevocable trust. That destroys part of the advantage of a rabbi trust, which is to have a safe cash fund available to pay the future compensation. Perhaps, there is a net value in a rabbi trust in reducing the employee discount rate without symmetrically reducing the employer discount rate by as much, but there will undoubtedly be trade-offs between the two discount rates.

In any event, deferred compensation offers a very good chance of correcting the major drawbacks of stock compensation. Stock plausibly has a higher discount rate on the holders' side than on the issuers' side. Deferred compensation offers a good chance of having a lower discount rate in the employee's evaluation of present value, while keeping a higher discount rate for the employer.

\section{Taxation of Stock and Deferred Compensation ${ }^{74}$}

Stock is often touted as a means by which to deliver capital gain to the employee ${ }^{75}$ Once the employee becomes the owner of stock, for example, the employer may redeem it back at fair market value and give the employee capital gain. ${ }^{76}$ Capital gain on stock held for more than a year is subject to tax of no more than $20 \% .{ }^{77}$

Capital gains plans, however, require that the employer give up the deduction of the benefit of the gain. Ordinarily, the employer deduction makes deferred compensation more valuable. Within a broad range, deferred compensation deductible by the employer will deliver a larger

73. The trust will be taxed as a grantor trust within I.R.C. $\S 461$, a deduction paid by a grantor trust shall be treated as paid by the grantor itself. See Priv. Ltr. Rul. 81-13-107 (Dec. 31, 1980); Treas. Reg. § 1.461-2(c) (1960).

74. This section relies on Calvin H. Johnson, Stock Compensation Under Section 83: A Reassessment, S. CAL. TAX INST. II 801.1-801.2 (1980). Model 2, herein, however is a reworking of TI 801.2 relying on the work of Alvin C. Warren, Jr., The Timing of Taxes, 39 NAT'L TAX J. 499, 501 (1986) and Daniel I. Halperin, Interest in Disguise: Taxing the "Time Value of Money," 95 Y ALE L.J. 506 (1986).

75. See, e.g., Senate Finance Committee, Revenue Act of 1964, S. Rep. No. 830, 88th Cong., 2d Sess. 88 (1964) (explaining that the Congress continued incentive stock option provisions giving capital gain to employees because incentives would be good for specific companies and also for the economy as a whole).

76. See I.R.C. $\$ 302$ (b) (1998) (providing that a redemption that is a complete termination of shareholder's interest or that reduces shareholder's fractional ownership by $20 \%$ will qualify as in "sale or exchange").

77. See I.R.C. $\S \S 1(\mathrm{~h})(1)(\mathrm{E}), 1222(3),(11)(1998)$. 
amount of after-tax benefit to the employee than will transactions that will give the employee capital gain.

This section develops two algebraic models of employee capital gain and then discusses which is applicable under various circumstances and what the models say about the advantages of cash plans versus stock plans as a way to pay future cash.

\section{Model 1: Appreciation Only}

Ordinarily, an employer deduction for appreciation on stock is more important than qualifying the appreciation as capital gain. Assume that a corporation sells $\$ 1000$ worth of its stock to a $44 \%$ tax rate employee for its fair market value. The stock appreciates for 10 years to be worth $\$ 11,000 .^{78}$ The corporation redeems the stock, giving the employee a net capital gain of $\$ 10,000 .{ }^{79}$ Naively, the employee is delighted to have that gain taxed at capital gain rates. Had the gain been treated as compensation, the employee would have paid tax of $44 \%$ or $\$ 4400$ and been left with only $\$ 6400$ after tax profit. As capital gain, the tax is $20 \%$, and the employee's after-tax profit is $\$ 8000$.

The naïve capital-gain position misses the benefit of the employer deduction that would have been available. An employer willing to devote $\$ 10,000$ net cash to the employee at the point of redemption of stock without a deduction should be willing to devote a larger amount to the employee if a deduction is available. A corporation in a $35 \%$ tax bracket can "gross up" the amount paid, reflecting the compensation deduction, to a larger pre-tax amount, at the same after-tax cost. The employer could pay $\$ 10,000 /(1-35 \%)$ or $\$ 15,385$ to the employee. The deduction of $\$ 15,385$ would have saved $35 \% * \$ 15,385$ or $\$ 5,385$, so that after tax, the cost would be the same $\$ 10,000$. The employee, however, gets $\$ 15,385$ in pre-tax cash. The employee tax is $44 \% * \$ 15,385$ or $\$ 6,769$. The employee's after-tax benefit is $\$ 15,385-\$ 6,769$ or $\$ 8,615$, that is, better than the $\$ 8000$ from the capital gain alternative.

Algebraically, the employee's after-tax position from the capital gain plan and deductible compensation plan can be compared as follows:

(1) $\$ 10,000[(1-T x) /(1-T c]$ versus $\$ 10,000(1-c g)$ where $T x$ represents the executive's tax rate, $T c$ represents the corporate employer's tax rate and $c g$ represents the capital gain tax.

At the values $T x=44 \%, T c=35 \%, c g=20 \%$, comparison (1) became:

(1A) $\$ 10,000[(1-44 \%) /(1-35 \%)]$ versus $\$ 10,000(1-20 \%)$ or

(1B) $\$ 10,000[86.15 \%]$ versus $\$ 10,000(80 \%)$ or

78. The appreciation is $27 \%$ per year because $\$ 1000 *(1+27 \%)^{10}=\$ 11,000$.

79. To qualify as capital gain, the redemption must completely terminate the employee's shareholder interest or reduce the employee-shareholder's fractional interest by more than $20 \%$ and leave her with less than $50 \%$ of the corporation's shares. See I.R.C. $\$ 302$ (b)(2), (3) (1998). The $20 \%$ reduction test would always be easier to meet, except that the complete termination test allows the employee to avoid constructive ownership of stock of family members in applying the $20 \%$ test, under certain circumstances. See I.R.C. $\$ 302(c)(1998)$. 
(1C) $\$ 8,615$ versus $\$ 8000$.

The model in comparison (1) does not mean that capital gain is never the better plan for the employee. To take a simple example, assume a corporation with tax shelters and net operating losses extending so far into the foreseeable future that the value of the compensation deduction is zero or trivial. Without value to the compensation deduction, the comparison (1) breaks down to a simple statement that the employee is better off with capital gains rates $(\mathrm{cg})$ than with ordinary tax rates $(T x)$.

A more general rule can be derived from comparison (1). The $\$ 10,000$ drops out of both sides of the comparison (1) leaving the rule that structuring the employee's gain as deductible compensation rather than capital gain will allow the employee to be better off after tax, whenever $(1-T x) /($ $1-T c>(1-c g)$. Stating the same relationship in a different way, the parties would be better off going for ordinary compensation rather than capital gain, whenever the corporation's tax rate is high enough to satisfy the following inequality:

(1D) Is $T c>1-(1-T x) /(1-c g)$ ?

For an employee in the highest tax bracket, the right side of the inequality $1 \mathrm{D}$ is $1-(1-44 \%) /(1-20 \%)$ or $1-(56 \% / 80 \%)$ or $14 \%$ : corporations with an effective tax rate of more than $14 \%$ when the stock is to be redeemed should abandon any capital gain plans for employees and switch to deferred compensation instead.

Model 2, as discussed next, implies that deferred compensation is better for the employee than capital gains plans without regard to the relative size of the employer's tax deductions.

\section{Model 2: Nullification of Capital Gain}

When capital arises on property given to the employee as compensation, capital gains plans are always worse than comparable cash plans that give the employer a deduction, at least within the scope of the assumption that tax rates remain constant. Deferring the employee's deduction until the cash is paid, gives the employee a benefit that is as good as not paying any tax on the subsequent capital gain. The employee should prefer the effectively-no-capital-gain tax position from deferred compensation to a plan that requires the employee to pay some positive capital gain.

Assume, for instance, that the $\$ 1000$ worth of stock was not sold to the employee (as in Model 1), but rather transferred to the employee as compensation. Assume now that the stock grows by growth rate $g$ over period $n$ by ten times so that the stock is worth $\$ 10,000^{80}$ and the employer redeems the stock back for its $\$ 10,000$ fair market value. In absence of tax, the employee would get $\$ 10,000$ in cash at the end of the period.

Stock compensation is deductible to the employee when paid, so the employer could gross up the compensation to an amount larger than the

80. What rate of growth $g$ the $\$ 10,000$ represents depends upon what period $n$ is allowed for growth. At $n=10$, for example, the growth is $26 \%$ per year. 
$\$ 1000$ pre-tax value when the stock was initially transferred, with the same after tax cost. Assume the employer grosses up the compensation with more stock to $\$ 1000 /(1-T c)$ - treating stock worth $\$ 1$ and real cash of $\$ 1$ as equivalents. The executive would pay tax of $T x$ on the grossed-up compensation. If we assume executive tax is paid by selling the compensatory stock itself, the employee has $\$ 1000 *[(1-T x) /(1-T c)]$ of the investment remaining after tax.

Assume again that the stock grows at rate $\mathrm{g}$ to $(1+g)^{\mathrm{n}}$ or ten times the original value. The employer could redeem the stock for the appreciated fair market value, giving the employee capital gain taxable at lower capital gain rate $c g$. Taxable capital gain is computed by subtracting the employee's basis from the amount realized. Algebraically, the employee's after-tax terminal position is:

(2) $\$ 1000 *[(1-T x) /(1-T c)] *(1+g)^{\mathrm{n}}-\boldsymbol{c g} *\{\$ \mathbf{1 0 0 0} *[(\mathbf{1}-\boldsymbol{T} \boldsymbol{x}) /(\mathbf{1}-\boldsymbol{T c})] *$ $\left.(1+g)^{\mathrm{n}}-\$ 1000 * *[(1-T x) /(1-T c)]\right\}$

The highlighted terms in Expression (2) represent capital gain tax on gain from the redemption of the stock. With values of $T x=44 \%, T c=$ $35 \%,(1+i)^{\mathrm{n}}=10$, and $c g=20 \%$, expression (2) becomes:

(2B) $\$ 1000 *[56 \% / 65 \%] * 10-\mathbf{2 0 \%}\{\$ \mathbf{1 0 0 0} *[\mathbf{5 6} \% / \mathbf{6 5 \%}] * \mathbf{9}\}=$

(2C) $\$ 8615-\mathbf{2 0} \%\{\mathbf{\$ 8 6 2} * \mathbf{9}\}=\$ 8615-\mathbf{\$ 1 5 5 1}=\$ 7,064$. The capital gains tax highlighted in (2B-2C) reduced the employees after tax benefit by $\$ 1551$.

\section{Deferred Compensation}

The entire impact of capital gains tax on the employee can be eliminated if the plan had only been a plan for deferred payment. In absence of tax, the transaction is $\$ 1000$ initial value of stock redeemed back for $\$ 10,000$ cash. If there is no initial transfer of stock, then there would be no deduction for income that would change the initial $\$ 1000$. When the employer pays $\$ 10,000$ in cash, however, there is both a deduction and income. An employer willing to pay $\$ 10,000$ in absence of tax upon redemption, should be willing to gross up the payment by $1 /(1-T c)$ to $\$ 15,384$. The executive receiving the $\$ 15,384$ would pay tax at $44 \%$ leaving $\$ 15,384 *(1-T x)$ or $\$ 8,615$. That after tax $\$ 8,615$ is exactly the same as (2C) as if there were no capital gains tax! The capital gains tax has been effectively nullified by delaying the compensation event until the employee needs the cash.

Algebraically, the nullification of the capital gain tax, by shift to cash compensation, can be expressed as:

(3A) $\$ 1000 *(1+g)^{\mathrm{n}} *[(1-T x) /(1-T c)]$

The terms of Expression (3A) can be rearranged:

(3) $\$ 1000 *[(1-T x) /(1-T c)] *(1+g) "$

Expression (3), describing the after tax position with deferred compensation, is exactly like Expression (2), except that there is no capital gain. Expression (3) is equivalent to Expression (2) without a capital gain tax, 
regardless of the values of ordinary income tax, employer tax, growth rate or time, or capital gains rates, so long as the values for $T x$ and $T c$ remain the same.

Expression (3), showing nullification of capital gain, is a variation of the Cary Brown thesis, which says that deferring tax on capital effectively lifts the tax on the subsequent income. ${ }^{81}$ Expression (3) applies not just if the employee is paid in stock, but also if the employee is paid in cash and buys stock. Employee capital gain is accordingly, not good tax planning and employee capital gain is no justification for stock over deferred compensation.

Expression (3) does assume that the corporate and individual tax rates are the same between the period when stock is awarded and the period when cash is paid. Sometimes the executives tax rate will be low when stock is awarded or the corporation's tax rate will be high. Under those circumstances, Expression (2) capital gain might be better than Expression (3) deferred compensation. The usual start-up company, however, goes from zero tax, when it has high development costs, ${ }^{82}$ into a higher tax once the products are successful. In that case, the deduction for deferred compensation will be much more valuable.

An employee can avoid capital gain tax included in the Expression (2) description by dying. ${ }^{83}$ If there is no capital gain tax in Expression (2), then Expression (3) for deferred compensation, effectively eliminating capital gain tax, is not an advantage. Still, Expression (3) does mean that deferred compensation gives the benefit of no capital gain tax without the executive having to die to get it.

Under Model 1, deferred compensation is better than capital gain plans only if $T c>(1-T x) /(1-c g)$, whereas Model 2 shows that deferred compensation is better than employee capital gain without regard to values for $T c, T x$ and $c g$. Looking only at capital gain appreciation, Expression (3) and Model 2 are more comprehensive descriptions of stock and deferred compensation than Model 1, because Model 2 shows the taxation of the capital that causes the capital gain appreciation. It is, thus, tempting to say that Model 2 is always superior to Model 1. As a matter of positive law, however, employees can get eligibility for capital gain, without having to pay tax on the capital that is appreciating. Employees can, for instance, be given an option to buy stock, and the appreciation on the stock long before they put any capital in, will nonetheless qualify as capital gain to the employee. ${ }^{84}$ Model 2 applies to what might be called "nat-

81. See, e.g., E. Cary Brown, Business-Income Taxation and Investment Incentives, in Income, Employment and Public Policy: Essays in Honor of Alvin H. Hansen 300 (1948); Dep'T Of THE Treasury, Blueprints For Basic Tax ReForm 123-24 (1977); Stanley S. Surrey, The Tax Reform Act of 1969 -Tax Deferral and Tax Shelters, 12 B.C. INT'L \& Comp. L. REV. 307 (1971).

82. I.R.C. $\$ 174(1998)$ allows the deduction of research or experimental costs when incurred.

83. See I.R.C. $\$ 1014$ (1998).

84. See I.R.C. $\$ \$ 421,422(1998)$. 
ural" or "normal" capital gain arising because of the appreciation of employee post-tax investment. Model 1, then, applies to employee capital gain that might be called abnormal or artificial employee capital gain. Model 1, however, says that even if the capital gain is forced or artificial for the employee, employee capital gain is not usually optimal tax planning.

\section{A NOTE ON COMPARING STOCK COMPENSATION WITH CURRENT CASH}

The primary focus of this article has been on comparing stock compensation with other ways to pay future cash. It has been assumed, as a jurisdictional fact, that current cash is not available to pay employees. Many start-up companies are so cash starved that they at least have the perception that use of cash is not a viable alternative. Nonetheless, some note should be taken of when stock compensation is superior to the use of current cash.

A corporation that makes an extraordinary return on invested cash might well be tempted to conserve its cash and use stock to pay employees instead. If internal investment generates a $12 \%$ compound return after inflation and taxes, then $\$ 1000$ will grow to $\$ 3.5$ million, in constantvalue terms, after seventy-two years. ${ }^{85}$ The corporation might well believe it will make $\$ 3.5$ million at the end of the stock redemption period by using a $\$ 1000$ stock bonus instead of $\$ 1000$ cash. The difficulty with the argument is that by giving the employee the $\$ 1000$ stock, the corporation has committed to the employee all of the $\$ 3.5$ million cash that the corporation will make by using the $\$ 1000$ cash. The historical shareholders get no advantage from using stock instead of cash because stock gives to the employee the after-tax cash that the corporation makes by withholding the immediate cash bonus.

There is a range in which the historical shareholders can profit by a switch from current cash to stock compensation. A corporation that beats its own track record, reflected in its stock price, on new investments can increase the average return on stock. If the corporation uses the discount rate on its own stock as a base line from which to judge its own investments, then it will go into those investments that improve its net worth overall. The return made on new high-rate-of-return investments will then be shared between historical shareholders and the new shareholder-employees. Stated another way, a corporation that can get a higher return on its investments than is reflected in its own stock price will be able to fund the future cash distribution on its stock at a present value cost of less than the price of the stock. By contrast, if the return on the new investment is less than the return on its old investments, the corporation will be sharing more with the new shareholder-employees than

85. $\$ 1000 *(1+12 \%)^{72}=\$ 3.5$ million. This is the example used in text accompanying, supra note 26 . 
it gets from the investment of the $\$ 1000$ withheld from the employee and replaced with stock. The standard for choice of stock versus current cash compensation is just a variation of the more general standard, first expressed by Irving Fisher, that a corporation should use the discount rate on its own stock as a base line in evaluating its investment opportunities. ${ }^{86}$ A corporation should distribute cash as dividends if it cannot find investments that give a return higher than the return reflected in the price of its own stock and so similarly a corporation should use cash instead of its own stock, if it cannot find investments that give a return higher than the return reflected by its own stock.

A corporation with access to high return investments should also be switching from current cash to future cash to pay employees, to the extent that employees will tolerate it. When the corporation switches to future cash, however, it should be using the optimal format to pay the future cash and stock is the least optimal way to pay future cash. The conclusion of this article is that the after-tax discount rates used by the market and executives to evaluate debt or deferred compensation are lower than the discount rate the corporation faces with stock. That means that the corporation should be using the lower discount rates from debt or deferred compensation as a standard to determine whether to pay current or deferred cash. If a corporation truly faces a negative after-tax and afterinflation interest rate on its debt, for example, as has occurred on average over long periods of time, then the corporation needs to defer all cash compensation to the future because the deferral makes the compensation cheaper. So long as the employer can make some positive-value use of its investable cash, compensation through negative-interest debt will leave the corporation ahead in net worth, judging from the negative interest rates available to corporations on average over the long term.

A corporation with attractive investments and an optimistic future can also use deferred compensation to take advantage of an asymmetry of discount rates that runs in favor of the corporation. Assume, for instance, that a corporation makes $12 \%$ after tax and after inflation, but general interest rates on secure promises are only $4 \%$ after tax. The corporation rewards an executive with $\$ 1$ million cash bonus, payable in ten years. To the corporate employer, the $\$ 1$ million payable to the executive has a present value cost of only $\$ 322,000$ given the 12 percent discount rate. ${ }^{87}$ Assume the executive views the future cash with only a $4 \%$ after-tax discount rate, however. At that discount rate, the $\$ 1$ million cash bonus will have a present value of $\$ 675,000 .^{88}$ The corporation is more than doubling the bang for its buck by taking advantage of the difference between its discount rate used to fund the bonus, and the lower discount rate the

86. See e.g., Miller \& Rock, supra note 51, at 1032; Copeland \& Weston, supra note 6 , at 18 (explaining the Irving Fisher criterion that corporations need to distribute earnings if projects available to it give a return less than the rate of return on the corporation's own stock).

87. $\$ 1,000,000 /(1+12 \%)^{10}=\$ 321,973$.

88. $\$ 1,000,000 /(1+4 \%)^{10}=\$ 675,564$. 
employee has access to. The difficulty that makes stock compensation so expensive is an asymmetry caused by tax and asymmetrical information that causes the employee to discount the cash at a much higher rate than the rate at which the corporation bears the cost of the cash. Once that diagnosis is understood, then the corporation can search for opportunities to reverse the asymmetry and pay by a method that is cheap to the corporation but valuable to the employee.

\section{CONCLUSION}

Stock compensation is an expensive means to compensate employees. Employer debt is cheaper because the discount rate used to evaluate the present value of the future cash is lower on debt than on stock, and because interest on debt is deductible. Deferred compensation is better than stock because the discount rate is lower and because deferred compensation is a more flexible way to give managers appropriate incentives. Deferred compensation, moreover, ordinarily gives the employee better benefits after tax than does employee capital gain. 